\title{
Corporate Social Responsibility Practices of Commercial Banks in Bangladesh: A Case Study on Southeast Bank Ltd.
}

\author{
Md. Kayssar Ahmed \\ Lecturer (Management) Department of Business Administration \\ Bangladesh Islami University, Dhaka, Bangladesh
}

\begin{abstract}
This paper explores how private commercial banks practices Corporate Social Responsibility (CSR) in Bangladesh in conserved the case of Southeast Bank Ltd.. In keeping with global movement, CSR is being seen as the source of new competition edge for the banking sectors of Bangladesh. Banks' of Bangladesh practices CSR to not only improve community relations but also as source of significant commercial benefit. Southeast Bank Ltd. practices CSR under the rules and regulation of Bangladesh Bank. The study based on annual report of 2012 of Southeast Bank Ltd. This study shows that Southeast Bank expenses BDT36.85 million in the year 2012 in the area of education, health, community development, environmental issue, art and culture, sports etc.. Nevertheless, bank expenses highest amount in education sector through scholarship program in Bangladesh whereby school, college and university education tuition and expenses have fully paid for unconditionally. The study can help banking manger's understand what should be done for the benefits of customers and the community for sustainability.
\end{abstract}

Keywords - Corporate Social Responsibility, Commercial Bank, Donation

\section{INTRODUCTION}

Management without caring needs and expectation of stakeholders in a community will not be competitive compared with those who do in the $21^{\text {st }}$ century. Demand for accountability and transparency from the both public and private sectors has become soaring. In the older days' management is seeking for survival and profits. Nowadays management concerns managing financial and nonfinancial results with awareness of risk and maintenance of transparency. As a result, Corporate Social Responsibility (CSR) has possessed equal importance of corporate financial performance (Yeung, 2011). There is an illusion/myth that CSR is just another name for philanthropy. Nevertheless, CSR is not just philanthropy it is more than that. CSR is a concept whereby companies integrated social and environmental concerns into their business operation and interaction with their stakeholders on a voluntary basis. CSR has internal and external practices. Internal refers to directly related with the physical and psychological working environment of employees. (Turker, 2009). It expressed in concern for the health and well being of employees, their training and participation in the business, equality of opportunities and work family relationship (Vives, 2006) while external CSR refers to responsibility for local community as well as business partners, suppliers, customers, public authorities and NGOs' representing local communities and the environment such as philanthropy, volunteerism and environmental protection (European Commission, 2001). CSR is not only ethical dilemma that financial institution face in an atmosphere of corrupt corporate practice (Azim et al. , 2011) but also these institution are concerned with commitment for sustainable development. Execution of such development procedure function through compliance with CSR guidelines is difficult. At present in Bangladesh CSR is a matter of self- interest for the corporate sector (Azim et al. 2009). There are 45 banks available most of them practices CSR as their main philanthropic manner. Southeast Bank Ltd. is one of the leading private commercial bank in Bangladesh who practices CSR in the last few years with huge CSR expenditures. In this study tried to find how Southeast Bank Ltd. practices CSR.

\section{LITERATURES REVIEW}

The importance of CSR has become an important issue for banks to address ahead of corporate scandals in the beginning of the century, which have had resulted in a side in the level of trust that they used to enjoy (Bdou et al. 2010)

Dusuki and Dar (2005) identifies several driving forces behind the growing trend towards CSR initiatives like growing market pressure on social and ethical issues, regularity pressure, increased power of communication etc.. This is true that banks are paying more to their CSR activities but not so much as their earning increase. Common CSR practices in Bangladesh by different Organization are centered on mainly poverty alleviation, healthcare, education, charity activates, cultural enrichment, youth development, women empowerment, patronizing sports and music etc. (Alam et al. 2010) 
Sharma (2011) in a study named CSR Practices and CSR Reporting in Indian banking sector mention CSR recognizes an organization's commitment to operate in a socially responsible manner. But CSR activities of developing nations are not so rosy. Particularly in financial sector there is an absence of stringent provisions regarding compliances and reporting CSR.

Wise and Ali (2009) In a paper entitled Corporate Governance and Corporate Social Responsibility in Bangladesh with special reference to commercial banks pointed out that corporate Social Responsibility is associated with corporate governance and ethical business procedure. Good corporate governance is expected to under pin effective and efficient corporate social responsibility within firms.

Masud and Hossain (2012) conduct a survey among 10 commercial banks and found that 100 banks reported their CSR activities but $60 \%$ banks participated in prescribe CSR area according to financial act.

The literature recognizes that CSR practices differ from country to country (Adams, Hill \& Robert, 1998) and between developed and developing countries (Imam, 2000). Furthermore, the nature and patterns of CSR vary between types of industry (Gray et al., 2001)

\section{OBJECTIVES OF THE STUDY}

The main objectives of this study are as follows:

- To know about the practices of CSR of Southeast Bank Ltd. ;

- To know the CSR area of Southeast Bank Ltd. where they perform CSR; and

- To make a recommendation.

\section{METHODOLOGY}

The study is exclusively a descriptive research and thus it is purely base on the information from the secondary data. The data collected for the purpose if the study involves the examination of annual reports for the year 2012 of Southeast Bank Ltd. 2012, it is documented that annual report is the most widespread and acceptance document (Belal 2000, Kkan et al. 2009; Khan 2010) for corporate communication in Bangladesh (Masud, 2011). Beside this, publications of Bangladesh Bank and other websites considered for data collection.

\section{FINDING AND ANALYZES}

\section{CSR practices of Southeast Bank Ltd. in Bangladesh}

The CSR activities of Southeast Bank Ltd. follow transparent business practices that are based on ethical values, compliances with legal and regulatory requirement and respect for people, communities and the environment. The bank is responsible for the totality of the impact on people and the plant, beyond making profit. Southeast Bank's banking practices is based on a network of relationship with its employees, customers, suppliers, business associated, shareholders, regulatory authorities and the community. The Bank's CSR is about addressing the needs of all the stakeholders in a way that advances its business and makes a positive and meaningful contribution to the society.

Table 1: Direct CSR Expenditures Reported by Southeast Bank Ltd.

(Taka in Millions)
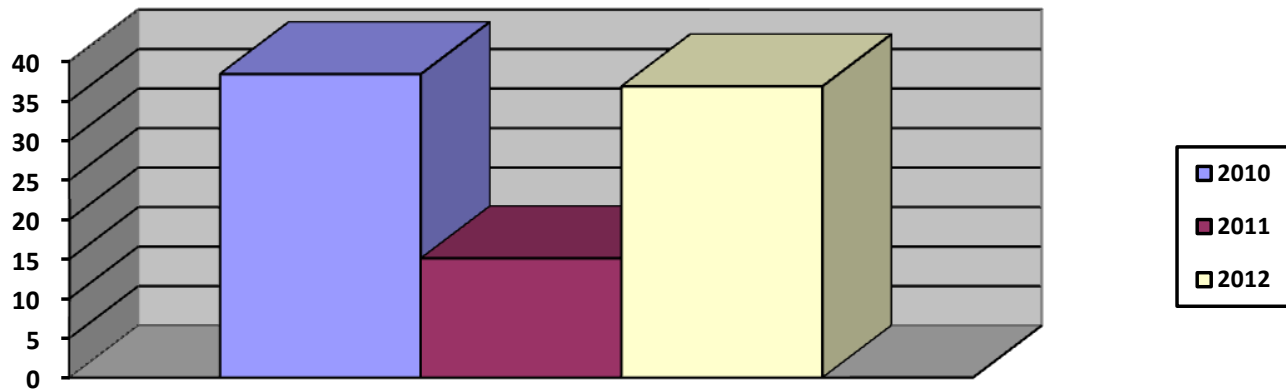

Source: Review of CSR initiatives of banks 2011 \& Annual report of Southeast Bank Ltd. 2012

The above graph shows that Southeast bank expended their CSR activities which increased year by year in 2010 Bank expended 38.40 million, 201115.10 million and at the year 2012 it is increase in taka 38.50 million. 
Table 2: CSR Expenditures as \% of Net Profit After Tax

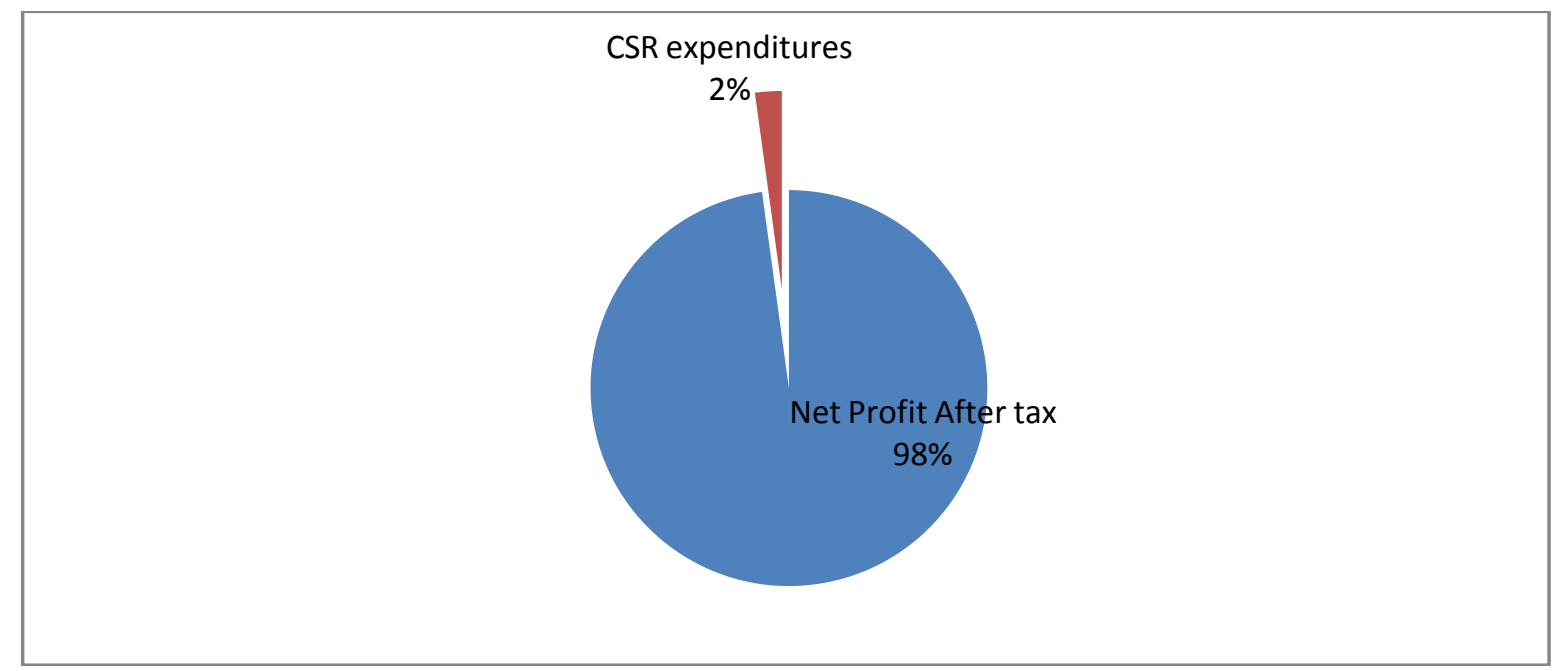

Source: Annual report of Southeast Bank Ltd. 2012

The above pie chart shows that in 2012 year southeast Bank expended taka 36.85 million which is the $2 \%$ of their net profit after tax.

Southeast Bank Ltd. now performs their social responsibility in some selected sectors. It's have a separate foundation called Southeast Bank Foundation (SEBF). Since inception in 2002, Southeast Bank Foundation (SEBF) has been working consistently to foster social advancement and wellbeing of the common people. The bank donates for education, sports, art, culture, health care, community development, environmental and relief etc.

\section{Education}

Education is the backbone of nation. No nation can develop without education. Keeping this view of mind, Southeast Bank Foundation has been working consistently from 2009. The main aim of this scholarship program is give scholarship at the meritorious students who are coming from low incomes families. SEBF begun with the two tiers: one for primary and secondary students and the other for higher secondary level students and later extended to higher education.

\section{Green School Project}

It is the first initiatives of banking sectors in Bangladesh that SEBF is developing a green school. Keeping the small children in mind and aiming to create an environment conductive to their comfortable learning SEBF has adopted policies, strategies, curricula, and the school facilities after thorough research and careful consideration.

Table 3: Total Contribution to Education Sectors by Bank

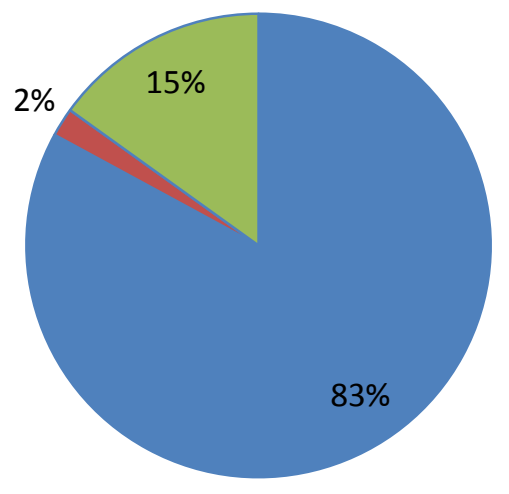

Scholarship Program

News Paper Distribution

$\square$ Green School Project 
From the diagram, we see that SEB spends $83 \%$ amount for scholarship program, $15 \%$ for newspaper distribution to various schools under scholarship project and 2\% for Southeast Bank Green School project out of total 20 million taka in 2012.

Table 4: No. of Benefited Students in Bank’s Scholarship Program

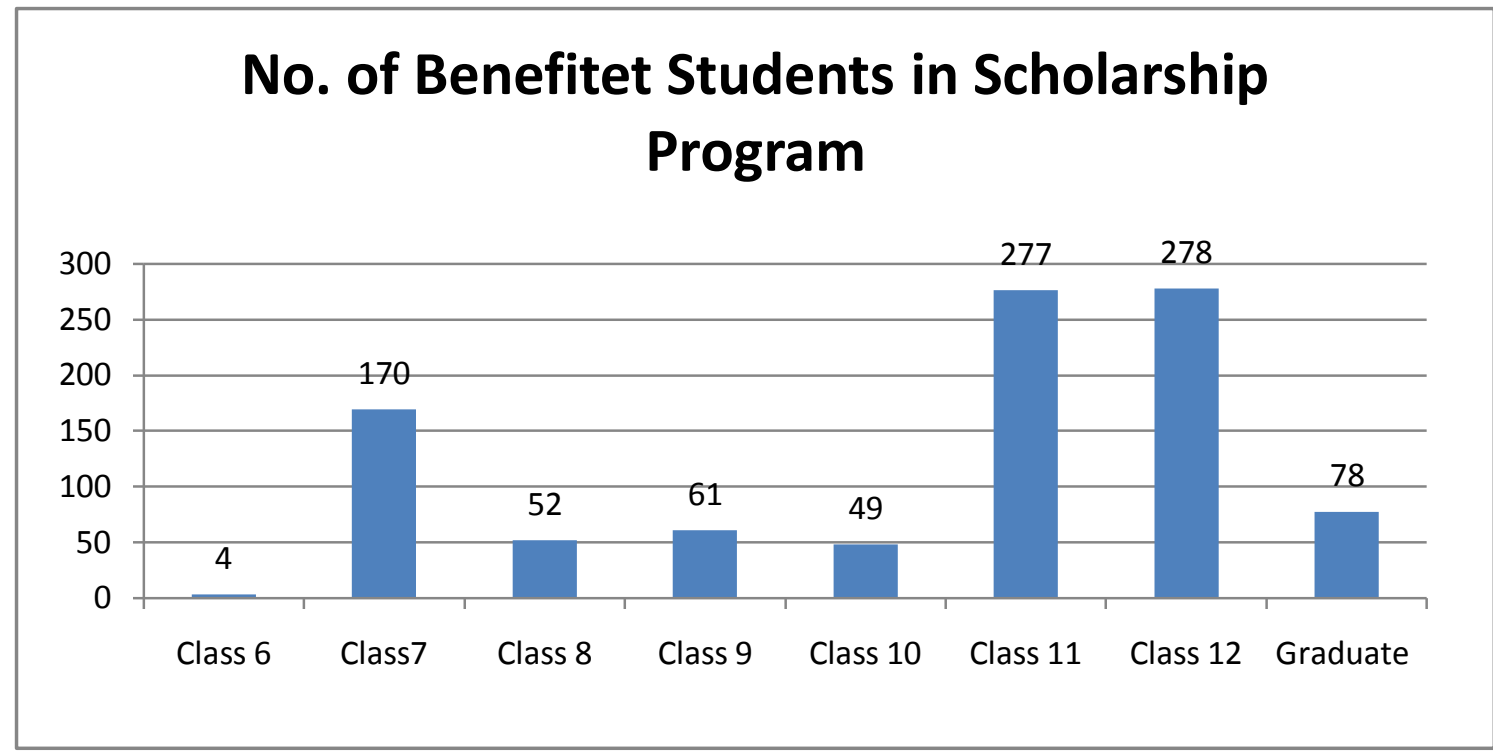

Source: Annual report of Southeast Bank Ltd. 2012

From the above diagram, in 2012 Southeast Bank provide scholarship among 969 students of different levels. In primary level from class 6 to class 10 total 336 students, 555 students in higher secondary levels and 78 students in graduate levels and sum total amount is BDT 16,641,200

\section{Health Sector}

Health is the most important strictures to achieve Millennium Development Goal (MDG). Southeast Bank donated BDT 3.37 million to different disadvantage people for medical treatment.

\section{Environment}

The bank continuously strives to ensure that its operations are environment-friendly and discourages financing protection and development. It is one of the leading participants in the beautification of Dhaka City. The beautification of the road-island from Russell Square to Manik Miah Avenue was done by the bank. Southeast bank donated BDT 100,000 to Bangladesh Bannya Prani Sheba Foundation for the development of Bannya Prani life style.

\section{Community Development}

Following the tragic incident of brutal killing of valiant Army officers at the then BDR Headquarters, Southeast Bank pioneered an idea to stand by the affected families. In accordance with this devised formula, the Bank, in collaboration with Government of Bangladesh donates following way:

Table 5: Contribution of Community Development by Bank

\begin{tabular}{|l|l|l|l|}
\hline $\begin{array}{l}\text { Total No. of Shaheed (Martyr ) } \\
\text { Army Family }\end{array}$ & Monthly Contribution & Yearly Contribution & Total Contribution \\
\hline 07 & BDT 40,000.00 & BDT 480,000.00 & BDT 3,360,00.00 \\
\hline
\end{tabular}

Source: Annual report of bank 2012

The table shows that 7 (seven) selected bereaved families of the Shaheed (Martyr) Army Officers is being given BDT 40,000.00 only per month and BDT 480,000.00 per yearly totally BDT 3,360,00.00 donated and the contribution will continue for next 10 years. 


\section{Art \& Culture}

Art and culture is the identity of a country. It represents the intellect and creativity of society as well of country. As a promising to the society, Southeast Bank promotes and nurture art and culture of Bangladesh. Here are a few note able initiatives:

Table 6: Bank's Contribution in the National Art and Culture

\begin{tabular}{|l|l|l|}
\hline \multicolumn{1}{|c|}{ Name of Organization/Individual } & \multicolumn{1}{|c|}{ Purpose } & Amount \\
\hline Alokito Nagari & $\begin{array}{l}\text { Donation for reception program for Dr. Anisuzzaman an, a } \\
\text { renowned researcher of the country }\end{array}$ & BDT 70,000.00 \\
\hline Forty years of celebration & Donation for celebration Forty Years of Independence & BDT 100,000.00 \\
\hline World Islami Economic Forum & Donation for a Round Table Conference & BDT 500,000.00 \\
\hline $\begin{array}{l}\text { Jatiya Robindra Songit Sommilon } \\
\text { Posishod }\end{array}$ & Donation for holding the conference & BDT 300,000.00 \\
\hline BCS Audit and Accounts Association & Sponsoring the Cultural Program and Dinner Party & BDT 300,000.00 \\
\hline RIDDHI & $\begin{array}{l}\text { Co-sponsoring the publication of the Book titled: Bangabandhu: } \\
\text { Shodesh Proticchobi }\end{array}$ & BDT 100,000.00 \\
\hline Sammilito Sangskritik Jote & Donation on the occasion of the Victory Day Festival-2012 & BDT 500,000.00 \\
\hline Chattagram Samity Dhaka & Donation for Annual Mezban Program & BDT 150,000.00 \\
\hline
\end{tabular}

Source: Annual report of bank 2012

The above table shows that Southeast Bank Ltd. donated a amount of BDT 2.02 million as for the development of art, culture and society.

\section{Other Contribution}

Donation to Common Wealth journalist Association

In 2012, Common Wealth Journalist Association attended a conference in Malta. Southeast Bank donates BDT 500,000.00 to Common Wealth Association for attending this conference.

\section{Donation to Dhaka University}

The 46th Convocation program of Dhaka University had held at the central playground of the varsity on March 31, 2012. Arranging the warm and glorious Convocation of Dhaka University banks sponsored BDT $1,000,000.00$

\section{Donate to Bangladesh Hockey Federation}

Bank sponsored the prestigious Bijoy Dibosh (National Victory Day) Office Hockey Tournament- 2012, which has held in Dhaka Hockey Stadium. Bank donates BDT 500,000.00 for this grand program.

\section{Donate to the Institute of Bankers, Bangladesh}

The Institute of Bankers, Bangladesh (IBB) establish as a professional body of banks and financial institutions in Bangladesh. The main functions of the institutions is to develop professionally qualified and competent bankers primarily through a process of training, examinations and continuing professional development programs. Southeast Bank donates BDT 2250,000.00 for purchase of floor space for its own premises.

\section{Financial Assistance to Family of late poet Shamsur Rahman}

Southeast bank handed a cheque of BDT 400,000.00 to the family members' late poet Shamsur Rahman.

\section{Southeast Bank Distributed Blanket to Distressed People}

Southeast Bank Ltd. has taken different program to distributed blanket to the western area. To save from the biting cold bank distribute blanket of total BDT 862,650 among the poor and needy people.

\section{Findings}

- Southeast Bank Ltd. expended a large amount of their profit as CSR activities.

- These expenditures are increase year by year.

- The practicing area of CSR in Southeast Bank Ltd. is mainly in education, health, community development.

- Southeast Bank Ltd. establish a green school which is first in banking sector of Bangladesh

- Southeast Bank Ltd. promotes different donation program for develop the life styles of society.

- Southeast Bank Ltd. is committed to meet the ethical values. 


\section{Recommendations}

Southeast Bank Ltd. can expand their social responsibility by the following way:

- Bank can invest in industries that produce social, cultural or religious development

- Bank can invest in green business

- Bank can patronized green IT sectors

- Donate in the eco friendly organization

- Ensure those investments that are harmful for the banks as well as their clients and environment

- Should provide the best service possible to the clients

- Create awareness among academics, managers, stakeholders

- Establish a fund to support the victim of natural disaster

\section{CONCLUSION}

It can be concluded from the study that all banking organization shall have appropriate policy in place for establishing positive organizational culture and social responsible mindset of stakeholders. If commitment for becoming a social responsible banking organization between management and stakeholders and accountability and creditability can be demonstrated through effective and efficient internal audit, customers and community also be benefited with risk reduced and quality enhanced. CSR is no longer exclusively practices in developing countries like Bangladesh are showing interest and commitment to CSR as well. Bangladesh consist many social problems. Government alone cannot solve this problem. As a business partners it is need to everyone specially commercial banks take part to reform the society. Because CSR is the more common place among banks, there are concerns the some banks promote an image of CSR whether or not they have true strategy in place and the results to show. Banks like Southeast Bank Ltd. came forward to contribute to the society. Though the contribution is limited the society but is the good initiative by banks. Southeast Bank Ltd. expended to CSR as because they believes that accountability and transparency are key contribute business in a responsible manner.

\section{REFERENCES}

[1]. Imam S, "Corporate Social Performance reporting in Bangladesh", Managerial Auditing Journal vol. 15, 2000 Pp. 133-141

[2]. Masud A. K.,'CSR practices of private commercial banks' in Bangladesh: A comparative study" MPRA paper no. 35496 online at http://mpra.ub.uni-muenchen.de/35496, 2011

[3]. Yeung S, "The Role of Banks in Corporate Social Responsibility" Journal of Applied Economics and Business Research,( JAEBR) Vol.1 No. 2, 2011, Pp. 13-115

[4]. Turker D., "Measuring Corporate Social Responsibility: A Scale Development Study" Journal of Business Ethic, 2009, Pp. 411-427

[5]. Vives A., "Social and Environmental Responsibility in Small and Medium Enterprises in Lating America" The Journal of Corporate Citizen,2006, Pp. 39-50

[6]. European Commission, "Promoting a European Framework for corporate Social Reposnibility Green Paper European Commission Directoriate- General for Employment and Social Affairs" Luxembourg. 2001 http://ec.europaeu/education/lifelong-learningpolicy/doc/mobility/com329-en.pdf (visited 15 May, 2013)

[7]. Azim M., Ahmed E. and Netto D. B., "Corporate Social Disclosure in Bangladesh: A study of the Financial Sector" International Review of Business Research Papers, Vol.7 No. 2 March 2011 Pp.37-55.

[8]. Azim M. I., Ahmed S. and Islam M. S.,"Corporate Social Reporting Practice: Evidence from Listed Companies in Bangladesh", Journal of Asia Pacific Business, Vol. 10 No. 02, 2009, 130-145

[9]. Dusuki A. W. and Dar H., "Stakeholders' Perception of Corporate Social Responsibility of Islamic Bank: Evidence from Malaysia Economy" Proceeding the sixth international conference on Islamic Economics, Jakarta Indonesia on 21-24n November 2005

[10]. Alam S. M. S. , Hoque S. M. S. and Hosen M. Z., "Corporate Social Responsibility of Multinational Corporation in Bangladesh: A case study on Grammen Phone” Journal of Pathuakhali Science and Technology University Vol. 02 No. 01 June 2010, Pp. 51-61

[11]. Masud M. A. K. and Hossain M. S., "Corporate Social Responsibility Reporting Practices in Bangladesh: A study of selected Private Commercial Banks" IOSR Journal of Business and Management (ISOR JBM) Vol.06 No. 2 Nov- Dec 2012 42-47

[12]. Sharma N., "CSR Practices and CSR Reporting in Indian Banking Sector" International Journal of Advanced Economics and Business Management Vol. 1 No. 2, 2011, Pp. 58-66

[13]. Wise V. and Ali M. M., "Corporate Governance and Corporate Social Responsibility in Bangladesh with Special Reference to Commercial Banks" AIUB BUS Econ Working Paper Series No 2009.05, 2009

[14]. Khan M. H., Islam M. A. and Ahmed K., "Corporate sustainability reporting of major commercial banks in line with GRI: Bangladesh evidence", Accepted for presentation in the $6^{\text {th }}$ Asia pacific Interdisciplinary Research on Accounting (APIRA) conference, to be held in the University of Sydney on 12-13 July 2010, Sydney Australia 